\title{
Next Generation Sequencing Analysis in Early Onset Dementia Patients
}

Cristian Bonvicinia ${ }^{\mathrm{a}, 1, *}$, Catia Scassellati ${ }^{\mathrm{a}, 1}$, Luisa Benussi ${ }^{\mathrm{a}}$, Emilio Di Maria ${ }^{\mathrm{b}}$, Carlo Maj ${ }^{\mathrm{c}, \mathrm{d}}$, Miriam Ciani $^{\mathrm{a}, \mathrm{e}}$, Silvia Fostinelli ${ }^{\mathrm{a}}$, Anna Mega ${ }^{\mathrm{f}}$, Martina Bocchetta ${ }^{\mathrm{f}, \mathrm{g}}$, Gaetana Lanzi ${ }^{\mathrm{h}}$, Edoardo Giacopuzzi ${ }^{\mathrm{c}, \mathrm{e}}$, Sergio Ferraboli ${ }^{\mathrm{e}}$, Michela Pievani ${ }^{\mathrm{f}}$, Virginia Fedi ${ }^{\mathrm{i}}$, Carlo Alberto Defanti ${ }^{\mathrm{j}}$, Silvia Giliani ${ }^{\mathrm{h}}$, Alzheimer's Disease Neuroimaging Initiative ${ }^{2}$, Giovanni Battista Frisoni ${ }^{\mathrm{f}, \mathrm{k}}$, Roberta Ghidoni ${ }^{\mathrm{a}}$ and Massimo Gennarelli ${ }^{\mathrm{c}, \mathrm{e}}$

${ }^{a}$ Molecular Markers Laboratory, IRCCS Istituto Centro San Giovanni di Dio Fatebenefratelli, Brescia, Italy

${ }^{\mathrm{b}}$ Department of Health Sciences, University of Genova and Division of Medical Genetics,

Galliera Hospital, Genova, Italy

${ }^{\mathrm{c}}$ Genetics Unit, IRCCS Istituto Centro San Giovanni di Dio Fatebenefratelli, Brescia, Italy

${ }^{\mathrm{d}}$ Institute for Genomic Statistics and Bioinformatics, Bonn, Germany

${ }^{\mathrm{e}}$ Department of Molecular and Translational Medicine, University of Brescia, Brescia, Italy

${ }^{\mathrm{f}}$ Laboratory Alzheimer's Neuroimaging and Epidemiology, IRCCS Istituto Centro San Giovanni di Dio Fatebenefratelli, Brescia, Italy

${ }^{\mathrm{g}}$ Dementia Research Centre, Department of Neurodegenerative Disease, UCL Queen Square Institute of Neurology, University College London, London, United Kingdom

h A. Nocivelli' Institute for Molecular Medicine Spedali Civili and University of Brescia, Brescia, Italy

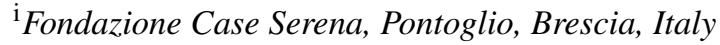

${ }^{\mathrm{j}}$ Fondazione Europea Ricerca Biomedica, Centro di Eccellenza Alzheimer, Ospedale Briolini Gazzaniga, Bergamo, Italy

${ }^{\mathrm{k}}$ Laboratory of Neuroimaging of Aging (LANVIE), University Hospitals and University of Geneva, Geneva, Switzerland; Department of Internal Medicine, University Hospitals and University of Geneva, Geneva, Switzerland

Handling Associate Editor: Stefan Teipel

Accepted 31 October 2018

\begin{abstract}
.
\footnotetext{
${ }^{1}$ These authors contributed equally to this work.

${ }^{2}$ Data used in preparation of this article were obtained from the Alzheimer's Disease Neuroimaging Initiative (ADNI) database (http://adni.loni.usc.edu). As such, the investigators within the ADNI contributed to the design and implementation of ADNI and/or provided data but did not participate in analysis or writing of this report. A complete listing of ADNI investigators can
}

Background: Early onset dementias (EOD) are rare neurodegenerative dementias that present before 65 years. Genetic factors have a substantially higher pathogenetic contribution in EOD patients than in late onset dementia.

Objective: To identify known and/or novel rare variants in major candidate genes associated to EOD by high-throughput sequencing. Common-risk variants of apolipoprotein $\mathrm{E}(A P O E)$ and prion protein $(P R N P)$ genes were also assessed.

be found at: http://adni.loni.usc.edu/wp-content/uploads/how_to_ apply/ADNI_Acknowledgement_List.pdf

*Correspondence to: Cristian Bonvicini, IRCCS "Centro S. Giovanni di Dio", Fatebenefratelli Via Pilastroni 4, 25123 Brescia, Italy. Tel.: +39 0303501 322; Fax: +39 0303501 597; E-mail: cbonvicini@fatebenefratelli.eu. 
Methods: We studied 22 EOD patients recruited in Memory Clinics, in the context of studies investigating genetic forms of dementia. Two methodological approaches were applied for the target-Next Generation Sequencing (NGS) analysis of these patients. In addition, we performed progranulin plasma dosage, $C 9 O r f 72$ hexanucleotide repeat expansion analysis, and $A P O E$ genotyping.

Results: We detected three rare known pathogenic mutations in the GRN and PSEN2 genes and eleven unknown-impact mutations in the GRN, VCP, MAPT, FUS, TREM2, and NOTCH3 genes. Six patients were carriers of only common risk variants (APOE and PRNP), and one did not show any risk mutation/variant. Overall, 69\% $(n=9)$ of our early onset Alzheimer's disease (EAOD) patients, compared with 34\% $(n=13)$ of sporadic late onset Alzheimer's disease (LOAD) patients and $27 \%$ $(n=73)$ of non-affected controls (ADNI, whole genome data), were carriers of at least two rare/common risk variants in the analyzed candidate genes panel, excluding the full penetrant mutations.

Conclusion: This study suggests that EOD patients without full penetrant mutations are characterized by higher probability to carry polygenic risk alleles that patients with LOAD forms. This finding is in line with recently reported evidence, thus suggesting that the genetic risk factors identified in LOAD might modulate the risk also in EOAD.

Keywords: Alzheimer's disease, common variants, early onset dementia, frontotemporal dementia, Lewy body dementia, next generation sequencing, rare mutations

\section{INTRODUCTION}

The term early onset dementias (EOD) refers to a group of progressive neurodegenerative diseases, e.g., Alzheimer's disease (AD), frontotemporal dementia (FTD), or dementia with Lewy bodies (LBD), affecting individuals aged between 45 and 65 years, and it represents roughly $5 \%$ of dementia cases [1]. The symptoms of EOD are similar to those of late onset AD (LOAD) and FTD. However, EOD is thought to be more severe and typically causes a rapid decline in health [2,3].

Both AD and FTD are pathologically heterogeneous disorders, characterized by a complex genetic architecture that is not yet completely understood. The heritability rates of the different dementia subtypes range from 40 to $80 \%$ with EOD showing a higher genetic component than late-onset dementia (for review [4]).

$\mathrm{AD}$ is clinically characterized by memory impairment and pathologically by the presence of amyloid- $\beta(\mathrm{A} \beta)$ peptide (the precursor of which is encoded by the $A P P$ gene) plaques and intraneuronal tangles of hyperphosphorylated forms of tau (a microtubule-associated protein encoded by the $M A P T$ gene). The risk AD spectrum is composed of Mendelian genetic traits, genetic population risk factors (susceptibility genes), and nongenetic risk factors such as low cognitive reserve and head trauma [5, 6]. The apolipoprotein E gene (APOE) $\varepsilon 4$ allele is a known population risk factor [7] that has been found to increase the risk of early onset AD (EOAD) [8]. Since its discovery, over 550 susceptibility genes have been suggested to increase the risk of AD [9], though the impact of most of these genes seems to be much lower than that of $A P O E[10,11]$. In particular, the common variants with small individual effects jointly modify the risk and age at onset of $\mathrm{AD}$ and dementia, showing a stronger effect in carriers homozygous for APOE $\varepsilon 4$ [12].

Three genes have been identified to carry causative mutations for familial EOAD: amyloid precursor protein $(A P P)$, presenilin $1(P S E N 1)$, and presenilin 2 (PSEN2) (for review [11]). The estimated mutation frequencies of these three genes are $1 \%$ for $A P P, 6 \%$ for PSEN1, and $1 \%$ for PSEN2. Together, they explain a genetic background of only $5-10 \%$ of EOAD patients, leaving a large group of autosomal dominant pedigrees genetically unexplained (for review [13]). This finding suggests that additional causal genes remain to be identified.

FTD is characterized by personality changes, language impairment, and deficits of executive functions associated with frontal and temporal lobe degeneration. At least nine autosomal dominant genetic traits have been associated with this pathology: mutations in $M A P T$, in the progranulin gene $(G R N)$, and in the hexanucleotide repeat expansion $C 9$ orf 72 genes are the most common, with the highest prevalence of $G R N$ mutations found in populations of northern Italy [14-17]. GRN null mutations cause protein haploinsufficiency, leading to a significant decrease in the circulating progranulin levels in plasma, serum, and cerebrospinal fluid (CSF) of mutation carriers [18-20]. Mutations in valosin-containing protein $(V C P)$, TAR DNA-binding protein 43 (TARDBP), charged multivesicular body protein $2 \mathrm{~B}(C H M P 2 B)$, fused in sarcoma (FUS), dynactin (DCTN1), and triggering receptor expressed on myeloid cell (TREM2) are rarer causes of this pathology [4,21]. Mutations in 
VCP [22], TARDBP [23], and TREM2 [24] have been observed in Italian families with a history of FTD.

Interestingly, mutations in some of these genes, such as MAPT, GRN, and C9orf72 have also been detected at low frequencies in AD patients, supporting the notion that a genetic heterogeneity exists for these diseases and that both diseases could form an AD-FTD disease continuum (for review [13]). An AD-like phenotype has also been described with the presence of a nonsense mutation in the prion protein gene (PRNP p.Q160*), which is responsible for inherited neurodegenerative spongiform encephalopathies [25]. In addition, the common coding polymorphism, methionine $(\mathrm{M})$ to valine $(\mathrm{V})$ at position 129 (M129V) in PRNP has been associated with EOAD, where the risk is higher for the VV genotype and is increased in patients with a positive family history [26].

The recent development of extremely powerful, massively, parallel DNA sequencing technologies allows for the systematic screening of individual genomes for DNA sequence variations at base-pair resolution, enabling researchers to address the missing hereditability question and, thus, to uncover novel and/or potentially pathogenic rare variants in candidate genes. As previously documented [27-29], targeted re-sequencing of a clinically significant gene panel may represent a powerful and cost-timeeffective technique compared to the previously used sequential Sanger sequencing.

Recently, Cruchaga et al. [30], confirmed that the genetic factors identified in LOAD modulate the risk also in EOAD cohorts, where the burden of these risk variants is associated with familial clustering and earlier onset of $\mathrm{AD}$. In the present study, we estimated the genetic load in EOAD and LOAD, by identifying known and novel, both rare and common risk variants in candidate genes. We applied next generation sequencing (NGS) analysis in a selected retrospective cohort of Italian EOD patients and compared the frequencies of variants found with those estimated in samples from the Alzheimer's Disease Neuroimaging Initiative (ADNI) database.

\section{MATERIALS AND METHODS}

\section{Participants}

A retrospective sample of patients was recruited in the context of studies investigating genetic forms of dementia at IRCCS Istituto Centro San Giovanni di Dio Fatebenefratelli, Brescia Italy, Fondazione Case
Serena, Pontoglio, Brescia, Italy, and Fondazione Europea Ricerca Biomedica, Centro di Eccellenza Alzheimer, Ospedale Briolini Gazzaniga, Bergamo, Italy. Specifically, twenty-two patients fulfilled the following inclusion criteria for the present study: 1) phenotype of $\mathrm{AD}, \mathrm{FTD}$, or LBD and 2) early disease onset ( $<65$ years old), or 3 ) family history suggestive of an autosomal dominant genetic form of dementia (i.e., high or medium risk of identifying a mutation according to Loy and Woods criteria [31, 32], as described below). Family history was collected through interviews with a first-degree relative or the spouse of the proband. The clinical and medical history of each family member was collected, and all of the available documentation for affected members was acquired. The probability of identifying a genetic mutation for AD or FTD was estimated considering the family medical history, the number of first and second-degree affected family members, and the age of symptom onset, according to the criteria developed by Loy and colleagues [31]. According to Loy et al.'s criteria for $\mathrm{AD}$, we defined a probability of identifying a genetic mutation of $\geq 86 \%$ as a high risk, a probability of $68-85 \%$ as a medium risk, a probability of $15-67 \%$ as a low risk, and a probability $<15 \%$ as apparently sporadic/unknown significance. Considering the same criteria for FTD patients, we considered an $\geq 88 \%$ probability of identifying a genetic mutation as a high risk, a $31-41 \%$ probability as a medium risk, and a probability $<13 \%$ as a low risk. FTD pedigrees were also scored according to Wood's pedigrees classifications criteria [32, 33].

All participants were of Italian ancestry. Demographic features and clinical data (age at onset, MMSE) are reported in Table 1. As the sample was retrospectively pooled for the analysis, a standard protocol for biomarker characterization was not applied. Sixteen patients underwent one of the following examinations as part of their diagnostic exam: magnetic resonance imaging (MRI), positron emission tomography (FDG-PET) or single photon emission computed tomography (SPECT), and/or lumbar puncture. MRI and PET/SPECT scans were visually evaluated to determine medialtemporal atrophy and hypometabolism, respectively. CSF samples were processed with local procedures to determine the level of $A \beta$, tau, and p-tau. Positive diagnosis was determined based on established cut-offs.

Blood samples were collected from all patients. DNA and plasma were obtained according to standard procedures. Patients provided written informed 


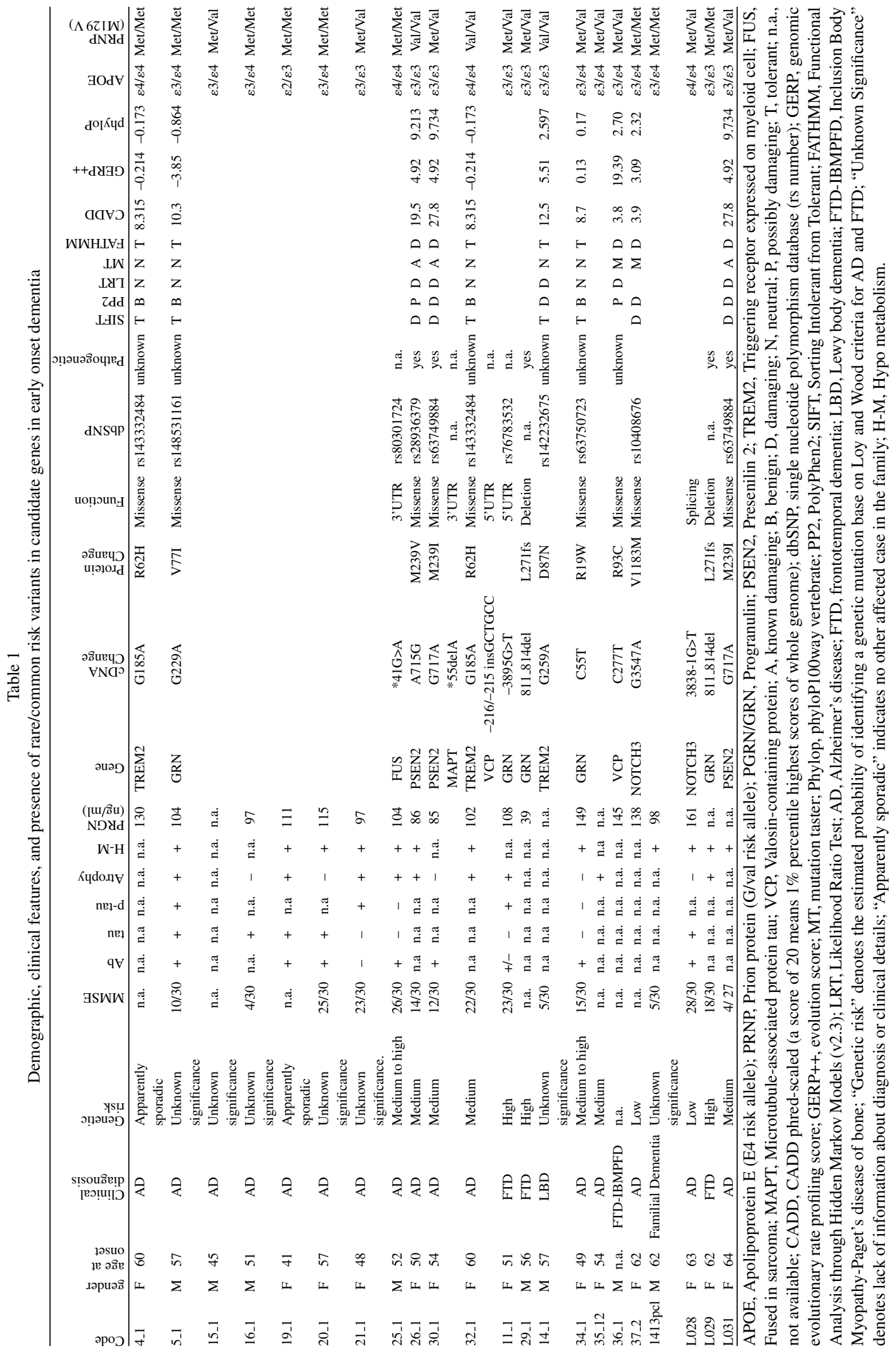


consent. This study was approved by the local ethics committee (CEIOC, 62/2013).

\section{NGS panel analysis screening}

Genomic DNA was extracted from whole-blood samples with a commercially available kit according to standard procedures (GENTRA Minneapolis, MN, USA).

Due to logistics issues, some samples were analyzed through the use of the Ion Torrent PGM (Thermo Fisher Scientific, Waltham, MA USA) sequencer as NGS platform, by using a candidates genes panel, already described in Beck et al. [27]. Briefly, for library construction, $5 \mathrm{ng}$ of genomic DNA were amplified using the Ion Ampliseq Dementia Research gene panel (Ampliseq ${ }^{\mathrm{TM}}$, Thermo Fisher Scientific, Waltham, MA USA), and the Ion Ampliseq ${ }^{\mathrm{TM}}$ Library kit 2.0, according to manufacturer's instructions. The generated amplicon library includes PRNP, PSEN1, PSEN2, APP (Amyloid Beta A4 Precursor Protein), GRN, MAPT, TREM2, CHMP2B, CSF1R (Colony Stimulating Factor 1 Receptor), FUS, ITM2B (Integral Membrane Protein 2B), NOTCH3 (Notch 3), SERPINII (Serpin Peptidase Inhibitor, Clade I (Neuroserpin), Member 1), TARDBP, TYROBP (TYRO Protein Tyrosine Kinase Binding Protein), VCP, SQSTMI (Sequestosome 1). Amplicons were ligated to Ion Torrent Barcodes/adapters P1 using DNA ligase. A first step of Agencourt AMPure XP bead (Beckman Coulter Inc., Brea CA, USA) purification was followed by nick-translation of adapter-ligated products and PCR-amplification. A second purification step using AMPure beads was performed and the concentration and size of the libraries were determined using an Agilent BioAnalyzer DNA High-sensitivity LabChip (Agilent Technologies, Santa Clara, CA USA). After dilution to $100 \mathrm{pM}$, libraries were clonally amplified on Ion sphere ${ }^{\mathrm{TM}}$ particles (ISP) by emulsion PCR with the Ion PGM ${ }^{\mathrm{TM}}$ template OT2 200 kit on the Ion One Touch 2 instrument according to the manufacturer's instructions (Thermo Fisher Scientific, Waltham, MA USA). ISP were enriched using the Ion One Touch ES module, loaded on an Ion 314 chip kit V2 and sequenced with an Ion Torrent PGM System (Thermo Fisher Scientific, Waltham, MA USA).

The remaining samples were analysed with the Illumina MiSeq platform and the TruSight One Sequencing Panel (Illumina, Inc., San Diego, CA, USA). This panel includes 125,395 probes targeting a $12-\mathrm{Mb}$ region spanning 4,813 genes, among which the genes investigated by Ion Torrent PGM (PRNP, PSEN1, PSEN2, APP, GRN, MAPT, TREM2, CHMP2B, CSF1R, FUS, ITM2B, NOTCH3, SERPINII, TARDBP, TYROBP, VCP, SQSTMI). The data regarding the other all genes were not used. The obtained sequence reads were aligned to the hg19 human reference sequence using the Burrow-Wheeler Aligner (BWA version 0.7.12). Duplicated reads were removed with Picard tools. Local realignment, recalibration, and variant calling were conducted with the Genome Analysis Tool Kit (GATK version 3.30). In order to have comparable results between the two sequencing approaches, we extracted from TruSight One Variant Call Format file (i.e., VCF file), the variants located in the regions sequenced by Ion Torrent PGM panel using BEDTools [34].

\section{APOE genotyping}

Genetic variation at the $A P O E$ locus was determined by using the SNaPshot technique [35]. Briefly, assays for the APOE polymorphisms were performed using PCR reactions, which were subsequently combined to perform a single SNaPshot reaction. The amplification assay was designed with the following forward and reverse primers: APOE F: 5' CCAAGG AGCTGCAGGCGGCGCA 3' and APOE R: 5' GCC CCGGCCTGGTACACTGCCA 3'. A product of PCRamplification was used as a template in the SNaPshot Multiplex assay. The following specific primers were used: SNAP APOE112:5' ACTGCACCAGG CGGCCGC 3' and SNAP APOE158:5' ATGCCGA TGACCTGCAGAAG 3'. Finally, the samples were analyzed, and allele peaks were determined using the ABI 3130xl genetic analyzer and the GeneMapper 4.0 program (Applied Biosystems, Foster City, CA, USA).

\section{C9Orf72 hexanucleotide repeat expansion}

PCR sizing of the GGGGCC hexanucleotide repeat was performed using previously published primers [36] on the ABI 3130xl genetic analyzer (Applied Biosystems, Foster City, CA, USA). The PCR reaction was carried out in a mixture containing 5\% dimethylsulfoxide and 7-deaza-2-deoxy GTP in substitution for dGTP. Allele identification and scoring were performed using GeneMapper v4.0 software (Applied Biosystems). 


\section{GRN plasma level measurement}

Plasma progranulin levels were measured in duplicate using an ELISA kit (Human Progranulin ELISA Kit, AdipoGen Inc., Seoul, Korea).

\section{Statistical and bioinformatics analyses}

To classify a variant as rare, its frequency should be lower than $1 \%$ in at least one of the three reference databases (1000 Genomes Project http://www.interna tionalgenome.org/, Exome Sequencing Project http:// evs.gs.washington.edu/EVS/ and Exome Aggregation Consortium http://exac.broadinstitute.org) [37].

In order to predict the functional consequences of non-synonymous variations, we exploited eight different bioinformatics tools, namely: SIFT, PolyPhen2, FATHMM, phyloP, MutationTaster, LRT, and CADD and GERP++ [38-45]. A variant is classified as damaging if for at least three tools the mutation is predicted to be deleterious.

Finally, to evaluate the mutation rate of the candidate genes selected in the NGS panel, we considered the gene damage index (GDI, a genome-wide, genelevel metric of the mutational damage that has accumulated in the general population), according to Itan et al. [46].

\section{ADNI whole genome data}

As a genetic replication cohort, we considered whole genome data from the ADNI database (http://adni.loni.usc.edu). From the whole genome data, we extracted the variants within the regions included in our sequencing panel and we applied the same variants annotation and classification performed for our sample.

The ADNI was launched in 2003 as a publicprivate partnership, led by Principal Investigator Michael W. Weiner, MD. The aim of ADNI project is to collect, validate and utilize heterogeneous clinical and biological data (including MRI and PET images, genetics, cognitive tests, CSF and blood biomarkers) to study the progression of AD. For up-to-date information, see http://www.adni-info.org.

\section{RESULTS}

Target screening: Plasma progranulin and C9ORF72 analyses

As a first step, progranulin plasma levels were assayed to screen for GRN null mutations (Table 1).
One FTD patient was found to have progranulin plasma levels lower than the optimized cut-off value for null mutations detection of $61.55 \mathrm{ng} / \mathrm{ml}[19,47]$. For 5 samples, it was no possible to detect the progranulin levels, due to the lack of plasma samples from these patients.

None of the EOD patients carried the pathogenic hexanucleotide repeat expansion of C9ORF72. All patients were found to have less than 12 repeats [48].

\section{NGS screening: Identification of known and unknown rare variants}

Through the target re-sequencing of the 17 candidate genes panel, we identified fourteen rare variants in $68 \%$ of the selected EOD cases (15 patients) (Table 1). These variants were defined as "pathogenic" when previously described in the literature, and they were classified as "damaging" by bioinformatic tools or as "unknown impact" when no data were available in literature and no deleterious effect was predicted by bioinformatics tools.

\section{Pathogenic variants}

Among the 14 identified rare variants, three were classified as pathogenic and damaging and have been described in Italian pedigrees unrelated to the patients analyzed in the present study. Two variants were located in the PSEN2 gene (p.M239V =rs28936379 code case: 26_1, [49]; p.M239I = rs63749884 code cases: 30_1, L031, [50]); and one variant was a p.L271fs null mutation in the GRN gene (code cases: 29_1; L029) (Table 1).

Finally, a heterozygous R93C mutation of the VCP gene was detected in a patient (Table 1, code: $36 \_1$ ) affected by Paget's disease of bone diagnosed at 44 of age and no signs of dementia at the last examination (47 years). Family history showed multiple individuals with FTD and Paget's disease with autosomal dominant inheritance.

\section{Variants of unknown impact}

Two variants in the TREM2 gene $(\mathrm{R} 62 \mathrm{H}=$ rs143332484, D87N = rs142232675, [51]) $($ Table 1) were observed in three of the 22 patients (14\%), including a patient with LBD.

Moreover, in $G R N$ gene, we found variants in the 5'UTR (rs76783532) and two rare missense variants $(\mathrm{V} 77 \mathrm{I}=\mathrm{rs} 148531161 ; \mathrm{R} 19 \mathrm{~W}=$ rs63750723; Table 1), which have been reported as "pathogenic nature 
unclear" and "not pathogenic", respectively, in online database (www.molgen.en.ua.ac.be/FTDmutations). Accordingly, these missense mutations did not influence the progranulin level in plasma (Table 1).

Other variants reported in online databases were those at 3'UTR of the FUS (rs80301724) and a missense mutation $(\mathrm{V} 1183 \mathrm{M}=$ rs 10408676) in NOTCH3 gene resulting "damaging" according to bioinformatics tools.

Moreover, we detected rare mutations which have not been reported in the literature and databases. In particular, we found a mutation localized in the $5^{\prime}$ UTR region and a missense mutation R93C (NM_007126: exon3: c.C277T:p.R93C) in the VCP gene, a deletion (NM_001203251:c.*55delA) in MAPT gene at 3'UTR region, a splicing variant (NM_000435: exon24: c.3838-1G>T) in NOTCH3 gene.

\section{Screening of known common variants}

All EOD patients were genotyped for the rs 429358 and rs7412 polymorphisms in the $A P O E$ gene and the rs1799990 polymorphism in the $P R N P$ gene. APOE $\varepsilon 4$ and $P R N P 129 \mathrm{Val}$ are known to be risk alleles. The results indicated that the frequencies of the $A P O E \varepsilon 4$ carriers and the PRNP 129Val carriers were $59 \%$ for both. Twenty (91\%) of the 22 subjects carried at least one of the two risk variants; of these subjects, 27\% (six out of 22) carried both the APOE $\varepsilon 4$ and the $P R N P 129$ Val risk alleles. Six patients were carriers of at least one risk allele (APOE $\varepsilon 4$ or PRNP 129Val) (Table 1).

One patient did not show any rare or common risk variants (Table 1).

\section{Comparison to whole genome data}

We compared and calculated the rare and common risk variants frequencies of the 17 candidate genes in our panel, with the data from the ADNI whole genome sequencing database. In the ADNI database, sporadic late-onset (38 patients), early onset (7 patients) $\mathrm{AD}$ cases, and 272 controls subjects were available. In our sample, the results indicated that, excluding the full penetrant mutations present in five patients, 9 patients $(69 \%)$ showed $\geq 2$ rare/common risk variants, compared with 13 (34\%) and $73(27 \%)$ observed in ADNI late-onset AD cases (LOAD) and controls, respectively (Chi-squared test: $\chi^{2}=15.8$, $\mathrm{df}=4, p=0.003$; Table 2). If we add to our sample, the seven EOAD patients coming from ADNI database (n tot $=20$ ), the percentage of genetic load did not change $\left(65 \%, n=13\right.$, Chi-squared test: $\chi^{2}=17.9$, $\mathrm{df}=4, p=0.001 ;$ Table 2).

\section{DISCUSSION}

This study suggests that EOD patients without full penetrant mutations are characterized by higher probability to carry polygenic risk alleles that patients with LOAD forms. This finding is in line with recently reported evidence [30], thus suggesting that the genetic risk factors identified in LOAD might modulate the risk also in EOAD.

Moreover, we confirmed the role of $G R N$ and PSEN2 genes in EOD, with the involvement of specific rare mutations already known. We also detected additional rare variants of unknown impact, located in the 5'/3' UTRs regulatory gene region of the $G R N$, $V C P, M A P T$, and $F U S$ genes, missense mutations in TREM2, GRN, NOTCH3, and VCP, genes and a splicing variant in NOTCH3 gene. According to the gene damage index (GDI) [46], mutations in these genes showed a value of "medium", suggesting that these genes are not frequently mutated in healthy populations. This finding further implies that mutations in these genes could be disease-causing.

\section{Rare mutations of known significance}

Twenty three percent of the cases carried one pathogenic mutation for dementia. In line with previous studies [14], mutations in the PSEN2 gene, a rare cause of dementia worldwide, were frequent in our cohort (14\%). Looking at the geographical distribution of PSEN2 mutations described to date, it is noteworthy that $80 \%$ of these mutations were uncovered in two southern European countries, Italy and Spain. Thus, we can speculate that the nonhomogeneous distribution of pathogenic mutations might be a result of genetic drift.

The GRN p.L271fs mutation is one of the most common GRN mutations worldwide. An analysis of this mutation in northern Italy showed that almost all families can be traced to a single founder. The origin of the mutation was dated to the Middle Ages at the turn of the first millennium, which explains the high frequency of this mutation in this geographic area [52].

\section{Rare mutations of unknown significance}

The role for novel variants of unknown significance in both common and rare dementia-associated genes 


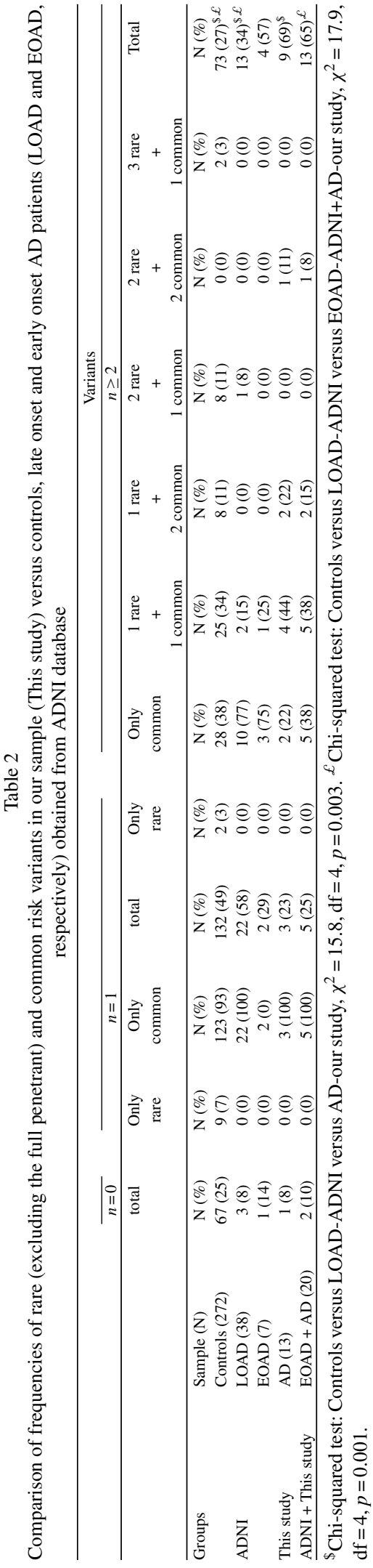

was not exhaustively elucidated. Recently, novel, likely pathogenic variants were described in Italian patients with dementia [53].

We found two AD patients carrying the $\mathrm{R} 62 \mathrm{H}$ mutation in the TREM2 gene, which has an unknown impact. A recent review on the correlation between TREM2 and AD [54], showed a meta-analytic association of this mutation with the late onset form of the disease. Our results also showed its involvement in the early onset form of AD. Since the two patients were also homozygous for the APOE $\varepsilon 4$ allele, this finding suggests interactions between TREM2 and $A P O E$, as already demonstrated in vitro $[55,56]$. TREM2 is a lipid sensor that interacts with several AD risk factors involved in lipid metabolism, including $A P O E$, which could decrease the threshold of disease occurrence [57].

In the specific case of two AD patients carrying the GRN p.V77I and R19W mutations, there is evidence of AD pathology in imaging and from biofluid biomarkers (Table 1). Since these missense mutations do not affect the progranulin levels, a pathogenic role of these mutations seems unlikely. However, we cannot exclude that they might have a pathogenic role other than "loss of function", as no functional studies have been performed. Their presence in AD patients might rather indicate that this gene could be implicated also in the pathophysiological mechanisms leading to AD dementia.

Our analyses showed the presence of additional rare variants located in the 5'/3' UTR regulatory gene region of the GRN, VCP, MAPT, and FUS genes. A recent study reported that 3'UTR SNPs, such as rs80301724 in the FUS gene, are present in microRNA binding sites and could impact the post-transcriptional regulation, resulting in overexpression of the protein [58]. Also missense mutations in TREM2, GRN, NOTCH3, and $V C P$ genes and a splicing variant in $\mathrm{NOTCH} 3$ gene were detected but, except for some information from bioinformatic tools, their specific functional impact was not assessed. The involvement of NOTCH3 gene in dementia patients is interesting, both with a missense and with a splicing variant. This gene encodes a single-pass trans-membrane protein of 2321 amino acids, predominantly expressed in vascular smooth muscle cells in adults. It is well documented that NOTCH3 mutations play a critical role in the pathogenetic mechanism of vascular smooth muscle cell degeneration linked to CADASIL, one of the most common hereditary forms of stroke [59]. A recent hypothesis of $\mathrm{AD}$ [60] suggested that in 
CADASIL triggering events in the pathogenic cascade are not amyloid deposits but damaged blood vessels caused by inflammatory reactions that lead to ischemia, amyloid accumulation, axonal degeneration, synaptic loss, and eventually irreversible neuronal cell death. Inflammation and blood vessel damage are well recognized complications of $\mathrm{AD}$, but what causes them and why the cerebral microvasculature is affected is still under debate [60]. Mutations in NOTCH3 gene are known to provoke inflammatory reactions and damage the brain in a wide variety of diseases [59], thus it is possible that one or more mutations in this gene may damage the microvasculature of the brain eventually leading that leads to dementia. The V1183M mutation was classified as a polymorphism in an Italian population [61], though the A allele frequency observed was 0.006 .

Inclusion body myopathy with Paget's disease of bone and/or FTD (IBMPFD) is a recently identified autosomal dominant disorder due to mutations in the $V C P$ gene affecting muscle, bone, and brain. Interestingly, in our cohort we found the R93C (47832C $>$ T) mutation in the $V C P$ gene already described in patients with IBMPFD [62-65].

\section{Common variants}

In this study, we investigated the most established common risk variant for $\mathrm{AD}$, the $A P O E \varepsilon 4$ haplotype. The functional role of this polymorphism in $\mathrm{AD}$ pathogenesis is unclear. However, there is now strong evidence that $A P O E \varepsilon 4$ could affect amyloid deposition [66]. Consistent with this evidence, in our cohort all APOE4 carriers with available CSF were amyloid positive (Table 1), except for the case code 19_1 of which we discuss separately (see below). The frequency of the $\varepsilon 4 / \varepsilon 4$ genotype ( $n=4,17 \%$, exact confidence interval 3-32\%) was higher than that commonly observed in the Caucasian population (1000 genomes), which is reported to be $2 \%$.

Moreover, we investigated the non-synonymous polymorphism p.Met129Val in the PRNP gene. Although there are no data on the functional effect of this polymorphism, we observed that the frequency of the risk variant allele G/Val was higher (59\%) than the frequency reported in the general European population (frequency $\mathrm{G} / \mathrm{Val}=33 \%$ reported by the Exome Aggregation Consortium). A recent meta-analysis showed that the p.Met129Val allele was associated with decreased disease risk in late-onset $\mathrm{AD}$, but not in EOAD [67].
Six patients from the present cohort carry only common risk variants. They could be sporadic cases with onset at the extreme end of expected age range. However, the hypothesis that EOD is caused by mutations in genes not included in the NGS panel cannot be ruled out. In this regard, whole genome sequencing could foster the investigation of additional genetic factors underlying apparently sporadic EOD. Nonetheless, this task was beyond the scope of the present work.

\section{Additional observations}

Interestingly, fifteen $(68 \%)$ of the 22 patients carried at least one rare variant (TREM2, GRN, PSEN2, $M A P T, V C P, N O T C H 3$, or FUS). Among these, fourteen subjects carried also a common variant (APOE and/or $P R N P$ ). This result supports the hypothesis that EOD results from the interconnected mechanisms leading to neurodegeneration, where multiple genes can be implicated in one or more systems. Indeed, recent biochemical approaches $[55,56]$ have shown interactions among these genes, such as between TREM2 and APOE in vitro. These results strongly implicate a potential additive/synergic effect in EOD forms linked to the variable inter- and intrafamiliar expressivity. To indirectly assess this effect, we found through the ADNI database that, excluding the full penetrant mutations, $69 \%$ of our sample showed $\geq 2$ rare/common risk variants, as compared to $34 \%$ and $27 \%$ in sporadic late-onset $\mathrm{AD}$ patients and controls, respectively. This indicates that the EOD is more often associated with rare variants or risk alleles, and this could be useful in the genotypephenotype correlations. Moreover, $<10 \%$ of subjects, in our cohort, and in late onset $\mathrm{AD}$ patients, compared to $25 \%$ in a control group, were not carriers of any of the examined variants, which strengthens the idea of using an NGS whole/exome genome approach in a larger sample.

One AD patient with a very early age of onset (41 years) showed neither rare nor common-risk variants. Even an exome clinic investigation detected no rare or common risk variants. The family history was negative, as no other first-degree relatives were affected (neither the parents nor three siblings, two of whom were older than the patient, presented with the disease). Misdiagnosis is unlikely since this patient was positive for all AD biomarkers (abnormal CSF amyloid and tau levels, hypometabolism on FDGPET, and medial temporal atrophy on MRI). Although we considered the possibility that the 
patient may show an extreme early-onset presentation of sporadic $\mathrm{AD}$, this finding suggests that additional genes could be implicated in EOD, which strengthens the evidence that the panel of candidate genes needs to be expanded in the future.

For the first time, the D87N mutation in the TREM2 gene was detected in a LBD patient with early onset. LBD is the second most common form of dementia after $\mathrm{AD}$, with a prevalence rate of $4 \%$ in the general population [68]. The core symptoms of LBD include sleep disturbances, hallucinations, and cognitive deficits, accompanied within the first year by Parkinsonian motor symptoms. A recent twin study did not show a strong support for a genetic contribution to LBD. However, other studies have demonstrated that LBD aggregates in families and may have an autosomal inheritance pattern (for review [4]). To date, a few genetic markers have been identified. For instance, duplication and SNPs within $\alpha, \beta, \gamma$-synuclein genes have been associated with increased risk of LBD [69, 70]. Moreover, mutations in the glucocerebrosidase $(G B A)$ gene are more common in LBD, in addition to mutations in the MAPT or leucine rich repeat kinase 2 (LRRK2) genes (for review [4]). Only one genome-wide linkage study has been performed among patients with familial LBD. A locus on chromosome 2q35-q36 was identified, though none of the genes in this region could explain the relation with LBD [71]. Although further confirmation is needed, the presence of a TREM2 mutation in an LBD patient adds a new actor to its genetic architecture. Mutations in TREM2, a microglial receptor, can lead to aberrant innate immune cell signaling, contributing to the initiation and propagation of several neurodegenerative phenotypes [72-83], including LBD. Moreover, this LBD patient was a carrier of the GG (Val/Val) PRNP risk genotype. This finding is in agreement with a previous study [84] that described a patient carrying the M232R mutation in the PRNP gene who developed dementia and died six years after onset. An autopsy revealed the patient had dementia with Lewy bodies, not Creutzfeldt-Jakob disease.

\section{Conclusions}

This study confirms the role of GRN and PSEN2 mutations in EOD, in the Italian population and provides evidence for roles of novel rare mutations located in the 5'/3' UTRs regulatory gene region of the GRN, VCP, MAPT, and FUS genes, missense mutations in TREM2, GRN, NOTCH3, and VCP, genes and a splicing variant in NOTCH3 gene, with a "medium" GDI value. As previously observed, mutations in the PSEN2 gene, a rare cause of dementia worldwide, are frequent in Italian patients. We also confirmed that mutations in $G R N$ gene were present in both FTD and AD phenotypes. Moreover, six patients were carriers of only common risk variants (APOE and PRNP), and one patient did not show any mutation/variant. Overall, 69\% $(n=9)$ of our EAOD patients, compared with $34 \%(n=13)$ of sporadic LOAD patients and $27 \%(n=73)$ of non-affected controls, were carriers of at least two rare/common risk variants in the analyzed candidates' genes panel.

Though our findings are consistent with results obtained from large cohorts [12], independent replications in larger samples are warranted. To further validate the role of polygenic risk variants in EOD, a systematic screening of rare and common variants in dementia-associated genes should be implemented in prospective cohorts with full clinical and biomarker characterization.

\section{ACKNOWLEDGMENTS}

This work was supported by the Italian Ministry of Health, Ricerca Corrente, RF-2010-2319722. We also acknowledge the University of Genova for partial support (Fondi ricerca Ateneo 2015 to EDM) and Dr. Irene Maria Briata for technical assistance.

ADNI data collection and sharing was funded by the Alzheimer's Disease Neuroimaging Initiative (National Institutes of Health Grant U01 AG024904) and DOD ADNI (Department of Defense award number W81XWH-12-2-0012). ADNI is funded by the National Institute on Aging, the National Institute of Biomedical Imaging and Bioengineering, and through generous contributions from the following: AbbVie, Alzheimer's Association; Alzheimer's Drug Discovery Foundation; Araclon Biotech; BioClinica, Inc.; Biogen; Bristol-Myers Squibb Company; CereSpir, Inc.; Cogstate; Eisai Inc.; Elan Pharmaceuticals, Inc.; Eli Lilly and Company; EuroImmun; F. Hoffmann-La Roche Ltd and its affiliated company Genentech, Inc.; Fujirebio; GE Healthcare; IXICO Ltd.; Janssen Alzheimer Immunotherapy Research \& Development, LLC.; Johnson \& Johnson Pharmaceutical Research \& Development LLC.; Lumosity; Lundbeck; Merck \& Co., Inc.; Meso Scale Diagnostics, LLC.; NeuroRx Research; Neurotrack Technologies; Novartis Pharmaceuticals Corporation; Pfizer Inc.; Piramal Imaging; Servier; Takeda 
Pharmaceutical Company; and Transition Therapeutics. The Canadian Institutes of Health Research is providing funds to support ADNI clinical sites in Canada. Private sector contributions are facilitated by the Foundation for the National Institutes of Health (http://www.fnih.org). The grantee organization is the Northern California Institute for Research and Education, and the study is coordinated by the Alzheimer's Therapeutic Research Institute at the University of Southern California. ADNI data are disseminated by the Laboratory for Neuro Imaging at the University of Southern California.

Authors' disclosures available online (https:// www.j-alz.com/manuscript-disclosures/18-0482r1).

\section{REFERENCES}

[1] van Vliet D, de Vugt ME, Bakker C, Koopmans RT, Verhey FR (2010) Impact of early onset dementia on caregivers: A review. Int J Geriatr Psychiatry 25, 1091-1100.

[2] Mendez MF (2006) The accurate diagnosis of early-onset dementia. Int J Psychiatry Med 36, 401-412.

[3] Jacobs D, Sano M, Marder K, Bell K, Bylsma F, Lafleche G, Albert M, Brandt J, Stern Y (1994) Age at onset of Alzheimer's disease: Relation to pattern of cognitive dysfunction and rate of decline. Neurology 44, 1215-1220.

[4] Ferencz B, Gerritsen L (2015) Genetics and underlying pathology of dementia. Neuropsychol Rev 25, 113-124.

[5] Paulsen JS, Nance M, Kim JI, Carlozzi NE, Panegyres PK, Erwin C, Goh A, McCusker E, Williams JK (2013) A review of quality of life after predictive testing for and earlier identification of neurodegenerative diseases. Prog Neurobiol 110, 2-28.

[6] Khanahmadi M, Farhud DD, Malmir M (2015) Genetic of Alzheimer's disease: A narrative review article. Iran J Public Health 44, 892-901.

[7] Roberts JS, Barber M, Brown TM, Cupples LA, Farrer LA, LaRusse SA, Post SG, Quaid KA, Ravdin LD, Relkin NR, Sadovnick AD, Whitehouse PJ, Woodard JL, Green RC (2004) Who seeks genetic susceptibility testing for Alzheimer's disease? Findings from a multisite, randomized clinical trial. Genet Med 6, 197-203.

[8] van Duijn CM, Hendriks L, Farrer LA, Backhovens H, Cruts M, Wehnert A, Hofman A, Van Broeckhoven C (1994) A population-based study of familial Alzheimer disease: Linkage to chromosomes 14, 19, and 21. Am J Hum Genet 55, 714-727.

[9] Freudenberg-Hua Y, Li W, Davies P (2018) The role of genetics in advancing precision medicine for Alzheimer's disease-a narrative review. Front Med (Lausanne) 5, 108.

[10] Bertram L, Lange C, Mullin K, Parkinson M, Hsiao M, Hogan MF, Schjeide BM, Hooli B, Divito J, Ionita I, Jiang H, Laird N, Moscarillo T, Ohlsen KL, Elliott K, Wang X, Hu-Lince D, Ryder M, Murphy A, Wagner SL, Blacker D, Becker KD, Tanzi RE (2008) Genome-wide association analysis reveals putative Alzheimer's disease susceptibility loci in addition to APOE. Am J Hum Genet 83, 623-632.

[11] Bagyinszky E, Youn YC, An SS, Kim S (2014) The genetics of Alzheimer's disease. Clin Interv Aging 9, 535-551.
[12] van der Lee SJ, Wolters FJ, Ikram MK, Hofman A, Ikram MA, Amin N, van Duijn CM (2018) The effect of APOE and other common genetic variants on the onset of Alzheimer's disease and dementia: A community-based cohort study. Lancet Neurol 17, 434-444.

[13] Cacace R, Sleegers K, Van Broeckhoven C (2016) Molecular genetics of early-onset Alzheimer's disease revisited. Alzheimers Dement 12, 733-748.

[14] Signorini S, Ghidoni R, Barbiero L, Benussi L, Binetti G (2004) Prevalence of pathogenic mutations in an Italian clinical series of patients with familial dementia. Curr Alzheimer Res 1, 215-218.

[15] Benussi L, Ghidoni R, Pegoiani E, Moretti DV, Zanetti O, Binetti G (2009) Progranulin Leu271LeufsX10 is one of the most common FTLD and CBS associated mutations worldwide. Neurobiol Dis 33, 379-385.

[16] Benussi L, Ghidoni R, Binetti G (2010) Progranulin mutations are a common cause of FTLD in Northern Italy. Alzheimer Dis Assoc Disord 24, 308-309.

[17] Benussi L, Rossi G, Glionna M, Tonoli E, Piccoli E, Fostinelli S, Paterlini A, Flocco R, Albani D, Pantieri R, Cereda C, Forloni G, Tagliavini F, Binetti G, Ghidoni R (2014) C9ORF72 hexanucleotide repeat number in frontotemporal lobar degeneration: A genotype-phenotype correlation study. J Alzheimers Dis 38, 799-808.

[18] Finch N, Baker M, Crook R, Swanson K, Kuntz K, Surtees R, Bisceglio G, Rovelet-Lecrux A, Boeve B, Petersen RC, Dickson DW, Younkin SG, Deramecourt V, Crook J, GraffRadford NR, Rademakers R (2009) Plasma progranulin levels predict progranulin mutation status in frontotemporal dementia patients and asymptomatic family members. Brain 132, 583-591.

[19] Ghidoni R, Benussi L, Glionna M, Franzoni M, Binetti G (2008) Low plasma progranulin levels predict progranulin mutations in frontotemporal lobar degeneration. Neurology 71, 1235-1239.

[20] Sleegers K, Brouwers N, Van Damme P, Engelborghs S, Gijselinck I, van der Zee J, Peeters K, Mattheijssens M, Cruts M, Vandenberghe R, De Deyn PP, Robberecht W, Van Broeckhoven C (2009) Serum biomarker for progranulinassociated frontotemporal lobar degeneration. Ann Neurol 65, 603-609.

[21] Tang SS, Li J, Tan L, Yu JT (2016) Genetics of frontotemporal lobar degeneration: From the bench to the clinic. $J$ Alzheimers Dis 52, 1157-1176.

[22] Viassolo V, Previtali SC, Schiatti E, Magnani G, Minetti C, Zara F, Grasso M, Dagna-Bricarelli F, Di Maria E (2008) Inclusion body myopathy, Paget's disease of the bone and frontotemporal dementia: Recurrence of the VCP R155H mutation in an Italian family and implications for genetic counselling. Clin Genet 74, 54-60.

[23] Ferrari R, Ferrara M, Alinani A, Sutton RB, Fama F, Picco A, Rodriguez G, Nobili F, Momeni P (2015) Screening of early and late onset Alzheimer's disease genetic risk factors in a cohort of dementia patients from Liguria, Italy. Curr Alzheimer Res 12, 802-812.

[24] Le Ber I, De Septenville A, Guerreiro R, Bras J, Camuzat A, Caroppo P, Lattante S, Couarch P, Kabashi E, BouyaAhmed K, Dubois B, Brice A (2014) Homozygous TREM2 mutation in a family with atypical frontotemporal dementia. Neurobiol Aging 35, 2419.e23-2419.e25.

[25] Collinge J (1997) Human prion diseases and bovine spongiform encephalopathy (BSE). Hum Mol Genet 6, 1699-1705.

[26] Dermaut B, Croes EA, Rademakers R, Van den Broeck M, Cruts M, Hofman A, van Duijn CM, Van Broeckhoven C 
(2003) PRNP Val129 homozygosity increases risk for earlyonset Alzheimer's disease. Ann Neurol 53, 409-412.

[27] Beck J, Pittman A, Adamson G, Campbell T, Kenny J, Houlden H, Rohrer JD, de Silva R, Shoai M, Uphill J, Poulter M, Hardy J, Mummery CJ, Warren JD, Schott JM, Fox NC, Rossor MN, Collinge J, Mead S (2014) Validation of nextgeneration sequencing technologies in genetic diagnosis of dementia. Neurobiol Aging 35, 261-265.

[28] Piccoli E, Rossi G, Rossi T, Pelliccioni G, D’ Amato I, Tagliavini F, Di Fede G (2016) Novel PSEN1 mutations (H214N and R220P) associated with familial Alzheimer's disease identified by targeted exome sequencing. Neurobiol Aging 40, 192.e7-192.11.

[29] Xu Y, Liu X, Shen J, Tian W, Fang R, Li B, Ma J, Cao L, Chen S, Li G, Tang H (2018) The whole exome sequencing clarifies the genotype- phenotype correlations in patients with early-onset dementia. Aging Dis 9, 696-705.

[30] Cruchaga C, Del-Aguila JL, Saef B, Black K, Fernandez MV, Budde J, Ibanez L, Deming Y, Kapoor M, Tosto G, Mayeux RP, Holtzman DM, Fagan AM, Morris JC, Bateman RJ, Goate AM, Dominantly Inherited Alzheimer Network (DIAN), Disease Neuroimaging Initiative (ADNI), NIA-LOAD family study, Harari O (2018) Polygenic risk score of sporadic late-onset Alzheimer's disease reveals a shared architecture with the familial and early-onset forms. Alzheimers Dement 14, 205-214.

[31] Loy CT, Schofield PR, Turner AM, Kwok JB (2014) Genetics of dementia. Lancet 383, 828-840.

[32] Wood EM, Falcone D, Suh E, Irwin DJ, Chen-Plotkin AS, Lee EB, Xie SX, Van Deerlin VM, Grossman M (2013) Development and validation of pedigree classification criteria for frontotemporal lobar degeneration. JAMA Neurol 70, 1411-1417.

[33] Fostinelli S, Ciani M, Zanardini R, Zanetti O, Binetti G, Ghidoni R, Benussi L (2018) The heritability of frontotemporal lobar degeneration: Validation of pedigree classification criteria in a Northern Italy Cohort. J Alzheimers Dis 61, 753-760.

[34] Quinlan AR, Hall IM (2010) BEDTools: A flexible suite of utilities for comparing genomic features. Bioinformatics 26, 841-842.

[35] Ingelsson M, Shin Y, Irizarry MC, Hyman BT, Lilius L, Forsell C, Graff C (2003) Genotyping of apolipoprotein E: Comparative evaluation of different protocols. Curr Protoc Hum Genet Chapter 9, Unt9.14.

[36] DeJesus-Hernandez M, Mackenzie IR, Boeve BF, Boxer AL, Baker M, Rutherford NJ, Nicholson AM, Finch NA, Flynn H, Adamson J, Kouri N, Wojtas A, Sengdy P, Hsiung GY, Karydas A, Seeley WW, Josephs KA, Coppola G, Geschwind DH, Wszolek ZK, Feldman H, Knopman DS, Petersen RC, Miller BL, Dickson DW, Boylan KB, GraffRadford NR, Rademakers R (2011) Expanded GGGGCC hexanucleotide repeat in noncoding region of C9ORF72 causes chromosome 9p-linked FTD and ALS. Neuron 72, 245-256.

[37] Bomba L, Walter K, Soranzo N (2017) The impact of rare and low-frequency genetic variants in common disease. Genome Biol 18, 77-017-1212-4.

[38] Kumar P, Henikoff S, Ng PC (2009) Predicting the effects of coding non-synonymous variants on protein function using the SIFT algorithm. Nat Protoc 4, 1073-1081.

[39] Adzhubei I, Jordan DM, Sunyaev SR (2013) Predicting functional effect of human missense mutations using PolyPhen-2. Curr Protoc Hum Genet Chapter 7, Unt7.20.
[40] Shihab HA, Gough J, Cooper DN, Stenson PD, Barker GL, Edwards KJ, Day IN, Gaunt TR (2013) Predicting the functional, molecular, and phenotypic consequences of amino acid substitutions using hidden Markov models. Hum Mutat 34, 57-65.

[41] Pollard KS, Hubisz MJ, Rosenbloom KR, Siepel A (2010) Detection of nonneutral substitution rates on mammalian phylogenies. Genome Res 20, 110-121.

[42] Schwarz JM, Rodelsperger C, Schuelke M, Seelow D (2010) MutationTaster evaluates disease-causing potential of sequence alterations. Nat Methods 7, 575-576.

[43] Chun S, Fay JC (2009) Identification of deleterious mutations within three human genomes. Genome Res $\mathbf{1 9}$, 1553-1561.

[44] Kircher M, Witten DM, Jain P, O'Roak BJ, Cooper GM, Shendure J (2014) A general framework for estimating the relative pathogenicity of human genetic variants. Nat Genet 46, 310-315.

[45] Davydov EV, Goode DL, Sirota M, Cooper GM, Sidow A, Batzoglou S (2010) Identifying a high fraction of the human genome to be under selective constraint using GERP++. PLoS Comput Biol 6, e1001025.

[46] Itan Y, Shang L, Boisson B, Patin E, Bolze A, MoncadaVélez M, Scott E, Ciancanelli MJ, Lafaille FG, Markle JG, Martinez-Barricarte R, de Jong SJ, Kong XF, Nitschke P, Belkadi A, Bustamante J, Puel A, Boisson-Dupuis S, Stenson PD, Gleeson JG, Cooper DN, Quintana-Murci L, Claverie JM, Zhang SY, Abel L, Casanova JL (2015) The human gene damage index as a gene-level approach to prioritizing exome variants. Proc Natl Acad Sci U S A 112, 13615-13620.

[47] Ghidoni R, Stoppani E, Rossi G, Piccoli E, Albertini V, Paterlini A, Glionna M, Pegoiani E, Agnati LF, Fenoglio C, Scarpini E, Galimberti D, Morbin M, Tagliavini F, Binetti G, Benussi L (2012) Optimal plasma progranulin cutoff value for predicting null progranulin mutations in neurodegenerative diseases: A multicenter Italian study. Neurodegener Dis 9, 121-127.

[48] Renton AE, Majounie E, Waite A, Simón-Sánchez J, Rollinson S, Gibbs JR, Schymick JC, Laaksovirta H, van Swieten JC, Myllykangas L, Kalimo H, Paetau A, Abramzon Y, Remes AM, Kaganovich A, Scholz SW, Duckworth J, Ding J, Harmer DW, Hernandez DG, Johnson JO, Mok K, Ryten M, Trabzuni D, Guerreiro RJ, Orrell RW, Neal J, Murray A, Pearson J, Jansen IE, Sondervan D, Seelaar H, Blake D, Young K, Halliwell N, Callister JB, Toulson G, Richardson A, Gerhard A, Snowden J, Mann D, Neary D, Nalls MA, Peuralinna T, Jansson L, Isoviita VM, Kaivorinne AL, Hölttä-Vuori M, Ikonen E, Sulkava R, Benatar M, Wuu J, Chiò A, Restagno G, Borghero G, Sabatelli M; ITALSGEN Consortium, Heckerman D, Rogaeva E, Zinman L, Rothstein JD, Sendtner M, Drepper C, Eichler EE, Alkan C, Abdullaev Z, Pack SD, Dutra A, Pak E, Hardy J, Singleton A, Williams NM, Heutink P, Pickering-Brown S, Morris HR, Tienari PJ, Traynor BJ (2011) A hexanucleotide repeat expansion in C9ORF72 is the cause of chromosome 9p21-linked ALS-FTD. Neuron 72, 257-268.

[49] Marcon G, Giaccone G, Cupidi C, Balestrieri M, Beltrami CA, Finato N, Bergonzi P, Sorbi S, Bugiani O, Tagliavini F (2004) Neuropathological and clinical phenotype of an Italian Alzheimer family with M239V mutation of presenilin 2 gene. J Neuropathol Exp Neurol 63, 199-209.

[50] Finckh U, Alberici A, Antoniazzi M, Benussi L, Fedi V, Giannini C, Gal A, Nitsch RM, Binetti G (2000) Variable 
expression of familial Alzheimer disease associated with presenilin 2 mutation M239I. Neurology 54, 2006-2008.

[51] Guerreiro R, Hardy J (2013) TREM2 and neurodegenerative disease. $N$ Engl J Med 369, 1569-1570.

[52] Benussi L, Rademakers R, Rutherford NJ, Wojtas A, Glionna M, Paterlini A, Albertini V, Bettecken T, Binetti G, Ghidoni R (2013) Estimating the age of the most common Italian GRN mutation: Walking back to Canossa times. J Alzheimers Dis 33, 69-76.

[53] Bartoletti-Stella A, Baiardi S, Stanzani-Maserati M, Piras S, Caffarra P, Raggi A, Pantieri R, Baldassari S, Caporali L, Abu-Rumeileh S, Linarello S, Liguori R, Parchi P, Capellari S (2018) Identification of rare genetic variants in Italian patients with dementia by targeted gene sequencing. Neurobiol Aging 66, 180.e23-180.e31.

[54] Cheng J, Guo X, Zhang T, Zhong L, Bu G, Chen X (2016) TREMs in Alzheimer's disease: Genetic and clinical investigations. Clin Chim Acta 463, 88-95.

[55] Atagi Y, Liu CC, Painter MM, Chen XF, Verbeeck C, Zheng H, Li X, Rademakers R, Kang SS, Xu H, Younkin S, Das $\mathrm{P}$, Fryer JD, Bu G (2015) Apolipoprotein E is a ligand for triggering receptor expressed on myeloid cells 2 (TREM2). J Biol Chem 290, 26043-26050.

[56] Bailey CC, DeVaux LB, Farzan M (2015) The triggering receptor expressed on myeloid cells 2 binds apolipoprotein E. J Biol Chem 290, 26033-26042.

[57] Colonna M, Wang Y (2016) TREM2 variants: New keys to decipher Alzheimer disease pathogenesis. Nat Rev Neurosci 17, 201-207.

[58] Manikandan M, Munirajan AK (2014) Single nucleotide polymorphisms in microRNA binding sites of oncogenes: Implications in cancer and pharmacogenomics. OMICS 18, 142-154.

[59] Masek J, Andersson ER (2017) The developmental biology of genetic Notch disorders. Development 144, 1743-1763.

[60] Marchesi VT (2016) Gain-of-function somatic mutations contribute to inflammation and blood vessel damage that lead to Alzheimer dementia: A hypothesis. FASEB J 30, 503-506.

[61] Ungaro C, Servillo P, Mazzei R, Consoli D, Conforti FL, Sprovieri T, Lanza PL, Quattrone A (2009) A pathogenic rare mutation on exon 22 of the NOTCH3 gene disclosed in an Italian patient affected by CADASIL. Neurol Sci 30, 269-271.

[62] Guyant-Marechal L, Laquerriere A, Duyckaerts C, Dumanchin C, Bou J, Dugny F, Le Ber I, Frebourg T, Hannequin D, Campion D (2006) Valosin-containing protein gene mutations: Clinical and neuropathologic features. Neurology 67, 644-651.

[63] Hubbers CU, Clemen CS, Kesper K, Boddrich A, Hofmann A, Kamarainen O, Tolksdorf K, Stumpf M, Reichelt J, Roth U, Krause S, Watts G, Kimonis V, Wattjes MP, Reimann J, Thal DR, Biermann K, Evert BO, Lochmuller H, Wanker EE, Schoser BG, Noegel AA, Schroder R (2007) Pathological consequences of VCP mutations on human striated muscle. Brain 130, 381-393.

[64] Krause S, Gohringer T, Walter MC, Schoser BG, Reilich P, Linn J, Popperl GE, Frolich L, Hentschel F, Lochmuller H, Danek A (2007) Brain imaging and neuropsychology in late-onset dementia due to a novel mutation (R93C) of valosin-containing protein. Clin Neuropathol 26, 232-240.

[65] Shi Z, Hayashi YK, Mitsuhashi S, Goto K, Kaneda D, Choi YC, Toyoda C, Hieda S, Kamiyama T, Sato H, Wada M, Noguchi S, Nonaka I, Nishino I (2012) Characterization of the Asian myopathy patients with VCP mutations. Eur $J$ Neurol 19, 501-509.

[66] Ramanan VK, Risacher SL, Nho K, Kim S, Swaminathan S, Shen L, Foroud TM, Hakonarson H, Huentelman MJ, Aisen PS, Petersen RC, Green RC, Jack CR, Koeppe RA, Jagust WJ, Weiner MW, Saykin AJ, Alzheimer's Disease Neuroimaging Initiative (2014) APOE and BCHE as modulators of cerebral amyloid deposition: A florbetapir PET genome-wide association study. Mol Psychiatry 19, 351-357.

[67] He J, Li X, Yang J, Huang J, Fu X, Zhang Y, Fan H (2013) The association between the methionine/valine (M/V) polymorphism (rs1799990) in the PRNP gene and the risk of Alzheimer disease: An update by meta-analysis. J Neurol Sci 326, 89-95.

[68] Knapp M, Prince M, Albanese E, Banerjee S, Dhanasiri S, Fernandez Plotka JL (2007) Dementia UK: The full report. Alzheimer's Society, London.

[69] Nishioka K, Wider C, Vilariño-Güell C, Soto-Ortolaza AI, Lincoln SJ, Kachergus JM, Jasinska-Myga B, Ross OA, Rajput A, Robinson CA, Ferman TJ, Wszolek ZK, Dickson DW, Farrer MJ (2010) Association of alpha-, beta-, and gamma-Synuclein with diffuse Lewy body disease. Arch Neurol 67, 970-975.

[70] Bras J, Guerreiro R, Darwent L, Parkkinen L, Ansorge O, Escott-Price V, Hernandez DG, Nalls MA, Clark LN, Honig LS, Marder K, Van Der Flier WM, Lemstra A, Scheltens P, Rogaeva E, St George-Hyslop P, Londos E, Zetterberg H, Ortega-Cubero S, Pastor P, Ferman TJ, Graff-Radford NR, Ross OA, Barber I, Braae A, Brown K, Morgan K, Maetzler W, Berg D, Troakes C, Al-Sarraj S, Lashley T, Compta Y, Revesz T, Lees A, Cairns N, Halliday GM, Mann D, Pickering-Brown S, Dickson DW, Singleton A, Hardy J (2014) Genetic analysis implicates APOE, SNCA and suggests lysosomal dysfunction in the etiology of dementia with Lewy bodies. Hum Mol Genet 23, 6139-6146.

[71] Bogaerts V, Engelborghs S, Kumar-Singh S, Goossens D, Pickut B, van der Zee J, Sleegers K, Peeters K, Martin JJ, Del-Favero J, Gasser T, Dickson DW, Wszolek ZK, De Deyn PP, Theuns J, Van Broeckhoven C (2007) A novel locus for dementia with Lewy bodies: A clinically and genetically heterogeneous disorder. Brain 130, 2277-2291.

[72] Benitez BA, Cooper B, Pastor P, Jin SC, Lorenzo E, Cervantes $S$, Cruchaga $C$ (2013) TREM2 is associated with the risk of Alzheimer's disease in Spanish population. Neurobiol Aging 34, 1711.e15-1711.e17.

[73] Cady J, Koval ED, Benitez BA, Zaidman C, JockelBalsarotti J, Allred P, Baloh RH, Ravits J, Simpson E, Appel SH, Pestronk A, Goate AM, Miller TM, Cruchaga C, Harms MB (2014) TREM2 variant p.R47H as a risk factor for sporadic amyotrophic lateral sclerosis. JAMA Neurol 71, 449-453.

[74] Cuyvers E, Bettens K, Philtjens S, Van Langenhove T, Gijselinck I, van der Zee J, Engelborghs S, Vandenbulcke M, Van Dongen J, Geerts N, Maes G, Mattheijssens M, Peeters $\mathrm{K}$, Cras P, Vandenberghe R, De Deyn PP, Van Broeckhoven C, Cruts M, Sleegers K, BELNEU consortium (2014) Investigating the role of rare heterozygous TREM2 variants in Alzheimer's disease and frontotemporal dementia. Neurobiol Aging 35, 726.e11-726.e19.

[75] Giraldo M, Lopera F, Siniard AL, Corneveaux JJ, Schrauwen I, Carvajal J, Muñoz C, Ramirez-Restrepo M, Gaiteri C, Myers AJ, Caselli RJ, Kosik KS, Reiman EM, Huentelman MJ (2013) Variants in triggering 
receptor expressed on myeloid cells 2 are associated with both behavioral variant frontotemporal lobar degeneration and Alzheimer's disease. Neurobiol Aging 34, 2077.e112077.e18.

[76] Guerreiro RJ, Lohmann E, Brás JM, Gibbs JR, Rohrer JD, Gurunlian N, Dursun B, Bilgic B, Hanagasi H, Gurvit H, Emre M, Singleton A, Hardy J (2013) Using exome sequencing to reveal mutations in TREM2 presenting as a frontotemporal dementia-like syndrome without bone involvement. JAMA Neurol 70, 78-84.

[77] Jin SC, Carrasquillo MM, Benitez BA, Skorupa T, Carrell D, Patel D, Lincoln S, Krishnan S, Kachadoorian M, Reitz C, Mayeux R, Wingo TS, Lah JJ, Levey AI, Murrell J, Hendrie H, Foroud T, Graff-Radford NR, Goate AM, Cruchaga C, Ertekin-Taner N (2015) TREM2 is associated with increased risk for Alzheimer's disease in African Americans. Mol Neurodegener 10, 19.

[78] Jonsson T, Stefansson H, Steinberg S, Jonsdottir I, Jonsson PV, Snaedal J, Bjornsson S, Huttenlocher J, Levey AI, Lah JJ, Rujescu D, Hampel H, Giegling I, Andreassen OA, Engedal K, Ulstein I, Djurovic S, Ibrahim-Verbaas C, Hofman A, Ikram MA, van Duijn CM, Thorsteinsdottir U, Kong A, Stefansson K (2013) Variant of TREM2 associated with the risk of Alzheimer's disease. N Engl J Med 368, 107-116.

[79] Korvatska O, Leverenz JB, Jayadev S, McMillan P, Kurtz I, Guo X, Rumbaugh M, Matsushita M, Girirajan S, Dorschner MO, Kiianitsa K, Yu CE, Brkanac Z, Garden GA, Raskind WH, Bird TD (2015) R47H variant of TREM2 associated with Alzheimer disease in a large late-onset family: Clinical, genetic, and neuropathological study. JAMA Neurol 72, 920-927.

[80] Ortega-Cubero S, Lorenzo-Betancor O, Lorenzo E, Agúndez JA, Jiménez-Jiménez FJ, Ross OA, Wurster I,
Mielke C, Lin JJ, Coria F, Clarimon J, Ezquerra M, Brighina L, Annesi G, Alonso-Navarro H, García-Martin E, Gironell A, Marti MJ, Yueh KC, Wszolek ZK, Sharma M, Berg D, Krüger R, Pastor MA, Pastor P (2015) TREM2 R47H variant and risk of essential tremor: A cross-sectional international multicenter study. Parkinsonism Relat Disord 21, 306-309.

[81] Rayaprolu S, Mullen B, Baker M, Lynch T, Finger E, Seeley WW, Hatanpaa KJ, Lomen-Hoerth C, Kertesz A, Bigio EH, Lippa C, Josephs KA, Knopman DS, White CL, Caselli R, Mackenzie IR, Miller BL, Boczarska-Jedynak M, Opala G, Krygowska-Wajs A, Barcikowska M, Younkin SG, Petersen RC, Ertekin-Taner N, Uitti RJ, Meschia JF, Boylan KB, Boeve BF, Graff-Radford NR, Wszolek ZK, Dickson DW, Rademakers R, Ross OA (2013) TREM2 in neurodegeneration: Evidence for association of the p.R47H variant with frontotemporal dementia and Parkinson's disease. $\mathrm{Mol} \mathrm{Neu}$ rodegener $\mathbf{8}, 19$.

[82] Rosenthal SL, Bamne MN, Wang X, Berman S, Snitz BE, Klunk WE, Sweet RA, Demirci FY, Lopez OL, Kamboh MI (2015) More evidence for association of a rare TREM2 mutation (R47H) with Alzheimer's disease risk. Neurobiol Aging 36, 2443.e21-2443.e26.

[83] Guerreiro R, Wojtas A, Bras J, Carrasquillo M, Rogaeva E, Majounie E, Cruchaga C, Sassi C, Kauwe JS, Younkin S, Hazrati L, Collinge J, Pocock J, Lashley T, Williams J, Lambert JC, Amouyel P, Goate A, Rademakers R, Morgan K, Powell J, St George-Hyslop P, Singleton A, Hardy J, Alzheimer Genetic Analysis Group (2013) TREM2 variants in Alzheimer's disease. N Engl J Med 368, 117-127.

[84] Koide T, Ohtake H, Nakajima T, Furukawa H, Sakai K, Kamei H, Makifuchi T, Fukuhara N (2002) A patient with dementia with Lewy bodies and codon 232 mutation of PRNP. Neurology 59, 1619-1621. 